\title{
Role of Water Research Institutions in Nepal and its Impact on Policy Changes
}

\section{Prachanda Pradhan}

$\mathrm{N}$ epalese believe that water is the elixir of life. As such, it has a very important role in the cultural development and economic change for any nation. We can see the value of water is embodied in the social, cultural, religious and economic actions of the people.

Many national and international institutions have focused on the economics of water and its relevance to national prosperity. But lately, that focus has turned to climate change and issues of scarcity. As the world has begun to recognize water as a limited resource with competing uses, research institutions have assumed an increasingly important role in assessing water conditions and suggesting policy for enhancing its judicious use. For example, in the 1990s, Integrated Water Resource Management (IWRM) was launched as a policy plan that many countries subsequently adopted. This was certainly the case in Nepal (Suhardiman,et., al 2015).

\section{Institutions Undertaking Water Research in Nepal}

So what is the role of dedicated water research institutions in Nepal? Many attempts were made to establish a national Water Research Institute but it did not materialize. The Water and Energy Commission Secretariat (WECS) was formed in 1975 as a research arm of the government. Its declared mission was supposed to collect, store and disseminate water related data for the purpose of policy formulation. While no one doubts the expertise and value of WECS, many debate if this group has been effectively used for its intended purpose.

There were attempts in the 1970s to establish a water research institute within the University system of Nepal, but the disciplinary divisions did not allow for this to happen. The engineering institutes of Nepal's university system held many summits to discuss to establish an institute but it, too, could not overcome the inter-disciplinary challenges that water presents. But today, the landscape of water research in Nepal is dominated by NGOs that more often work separately than together.

As a career researcher on water issues, in this paper, I want to discuss some of my experiences and how they suggest that Nepal must continue to work toward establishing a stronger system of water research and policy development.

Starting in the 1950 s, irrigation systems began to spread and develop around Nepal. In 1952, the Department of Irrigation was formed. Two graduate students from Cornell University in late 1970s (Robert Yoder and Edward Martin) launched a Ph.D. project that sought to bring together competing irrigation systems in a design that would encourage more judicious use and better cooperation among users: Farmer Management Irrigation Systems (FMIS). Yoder and Martin focused on the management perspective and drew up a plan that would stress the importance of the individual farmer as the key role for water use. The features of FMIS can be attributed as follows. (a) Water is considered as a community property, (b) Water allocation is done within the community, (c) Based on water allocation, water distribution is done, (d) Water allocation is transparent, (e) Resource mobilization is based on the amount of water title, (f) Water title implies obligations of the users so that $\mathrm{O} \& \mathrm{M}$ is done on that basis, (g) In order for the fulfillment of obligations, record of the landholding and beneficiary list is kept, (h) Decisions are made in the general assembly and executive committee implements them, (i) In order to see the implementation of the rules and regulations of the system, users committee is formed and it is accountable to the general assembly, (j) Nonadherence of the rules will be subject to punishment which will be collectively decided and implemented the punishment collectively, (k) Rules and regulations (may be written or unwritten) are known to all members of the community, (l) All these features are possible because of strong social capital development in the irrigators community over long period of time. At this point, FMIS became the guiding perspective for irrigated agriculture. (Pradhan 2007).

Then in the 1980s, two important research institutes arrived in Nepal: the International Water Management Institute (IWMI) and the International Centre for Integrated Mountain Development (ICIMOD). Both of these groups have water as a central mandate for their operating plans. ICIMOD focuses particularly on the Hindu-Kush mountain region where water is a frequently scarce and a source of tension among neighboring countries. IWMI, meanwhile, assumed responsibility to oversee FMIS work in Nepal. Today, both of these groups work closely with WECS and other government agencies with a water-related objective.

IWMI was charged with identifying an appropriate intervention strategy for the Indrawati Watershed Basin using FMIS principles. They assisted 19 irrigation systems to develop a cooperation plan that optimized water use without depleting available resources while minimizing the economic impact to individual farmers (Ostrom et al. 2011). Many of the lessons gleaned from this project where drawn into the government's Irrigation Master Plan and the Mechi Hill Irrigation Development Project. In particular, these documents noted the participatory approach employed to find proper solutions.

Inspired by the success of IWMI's work in the Indrawati Basin, Institute of Agriculture and Animal 
Science, Tribhuvan University established an irrigation study group to provide information and expertise to future irrigation plans. They collaborated heavily with political scientist Elinor Ostrom and Indiana University to activate this research organization. IWMI would provide the seed money to the irrigation study group as they conducted an FMIS inventory of the East Rapti area. Ostrom established Nepal Irrigation Institute Data base and she concluded that neither the private sector nor the government could properly manage natural resources. Instead, she suggested, the community must decide the proper means for water governance. Based on this work, Ostrom received the Nobel Prize for economics in 2009. She cited her work with FMIS in her acceptance speech.

On the policy side, the government of Nepal passed the Water Resources Act in 1992, which included long overdue definitions of water rights. The Act declared that the water belongs to the government, but allows for the customary user rights of farmers. The Act also included provisions to form Water User Associations (WUA), which would register with local districts to organize and define local water rights. The Water Resources Act was quickly followed by a new Irrigation Policy. This new draft incorporated many principles of FMIS, in particular its stress on the autonomy of local user rights.

FMIS continued to gain a larger role in water planning visions. After the increase of IWMI's role as a research institute, they also along with other researchers supported the establishment of a Farmer Managed Irrigation Systems Promotion Trust, whose funds are dedicated to research intended to inform better policy innovations and advocacy role (Pant 2010). IWMI has also turned its focus to agrarian issues in Nepal and their impact on water, irrigation and food productivity. Similarly, studies on climate change and women's role in water use decisionmaking has also received significant attention.

Locally, very important Nepal-based water institutes have formed in the last 15 years and assumed a crucial role in generating and disseminating important research and editorials on the future of water. These include the Nepal Water Conservation Foundation, headed by former Minster of Water Resources Dipak Gyawali, and Jalsrot Vikas Sanstha, which features an impressive board of water experts covering topics from law and hydrology to policy formation and history. More and more these groups are finding voice to influence government decisions.

The importance of these national and international research institutes becomes more clear when we focus on local examples of water and its relations to prosperity and human well-being (Pradhan 2012). The Rasuwa and Dolakha districts used to be called poor areas, but if assessed on the amount of water available, then they would be considered wealthy. How would we judge Humla and Jumla districts by this metric? If there is a relationship between water scarcity and poverty, then leaving rivers untapped seems like mistake. How can these waters be used to enrich people?
This should be the main focus of research institutes going forward. How can they develop policies and laws that will provide long-term sustainable river use? How can they work with the media to bridge existing information gaps between the public and policy makers? These are big challenges. But in the next 50 years, it will be necessary for Nepal to surmount these challenges if it wants to raise the national standard of living.

Prachada Pradhan, born in March 1939, was Professor of Public Administration in Tribhuban University, Kathmandu, Nepal. In 1972-75, he was Dean of Institution of Business Administration, Commerce and Public Administration, Tribhuban University, Nepal. He earned his Ph.D. in Government from Claremont Graduate School and University Center, Claremont, California, in 1969. He was a Research Associate at John Kennedy School of Government, Harvard, in 1972, and a Fulbright Visiting Professor at Center for International Studies, Cornell University, in 1979 and Visiting scholar at Workshop in Political Theory and Political Analysis, Indiana University, USA in 2002. He has several books to his credit. He has worked in national and international organizations including worked at International Irrigation Management Institute (IIMI) based in Sri Lanka from 1986 to 1993. He has worked in Nepal, Bhutan, India, Bangladesh, Sri Lanka, Pakistan, Lao PDR, Vietnam, Nigeria, Niger and Guyana.

\section{References}

Ostrom, Elionor, Wai Fung Lam, Prachanda Pradhan and Ganesh Shivakoti, 2011. Improving Irrigation in Asia: Sustainable Performance of Innovative Intervention in Nepal. Edward Elgar. Cheltenham, UK.

Pant, Dhruba. 2010. "FMIS Research: A Reflection on IWMI 's 25 Years in Nepal" in Prachanda Pradhan Upendra Gautam and Naveen M. Joshi (eds.). Dynamics of farmer Managed Irrigation Systems in Nepal, Socio-Institutional, Institutional and Technical Context, Kathmandu: FMIST

Pradhan, Prachanda.2007. "Twenty Five Years FMIS Study in Nepal" in Prachanda Pradhan, Laya Uprety, et. al. (eds.). Irrigation in Transition Interacting with Internal and External Factors and Setting the Strategic Action, Kathmandu: FMIST

Pradhan, Prachanda. 2012." Results of Unplanned Programs: Drinking Water and sanitation System in Bhaktapur, Nepal in Anjali Prakash , et.al.( eds.). Interlacing Water and Human Health, New Delhi, (India): Sage Publication

Suhardiman, Diana, Floriane Clement and Luna Bharati. 2015. "Integrated Water Resources Management in Nepal: Key stakeholders Perceptions and Lessons Learned. International Journal of Water Resources Development, DOI (http://dx.doio $\mathrm{rg} / 10.1080 / 07900627.2015 .1020999$ ) 